\title{
Density Account of Cyanobacteria (Genus: Trichodesmium) in Selected Cebu Provinces, Philippines
}

\author{
Adriano R. Melendres, Jr. MSc ${ }^{1}$, Filipina B. Sotto $\mathrm{PhD}^{2}$ \\ ${ }^{1}$ Cebu Technological University-Carmen and 2University of San Carlos - Talamban
}

*Corresponding Author: Adriano R. Melendres, Cebu Technological University- Carmen and 2University of San Carlos - Talamban

\begin{abstract}
This study investigated the density of genus Trichodesmium on the coastal water of Carmen, DaanBantayan, Balamban, and Dalaguete, Cebu Philippines. Major objective was to account the density of Trichodesmium species in selected sampling sites. Field collection was performed in 4 sampling sites from July to September 2017. There were only 2 identified cyanobacteria species belonging to genus Trichodesmium.T. erythraeum were the dominant in Carmen, with total number of 629 (89.86\%), while highest density of T. thiebautii was 3959 (99.27\%) in Daan-Bantayan. The relative density per species was also computed. The present study indicated that Trichodesmium thiebautii was also comparable to Dalaguete and Balamban. It was suggested to perform field collection during dry season and summer for comparison.
\end{abstract}

Keywords: cyanobacteria, nitrogen fixation, trichomes, density, characterization.

\section{INTRODUCTION}

Cyanobacteria of the genus Trichodesmium contribute significant amounts of nitrogen $(\mathrm{N})$ to tropical and subtropical oligotrophic oceans through $\mathrm{N}_{2}$ fixation (Capone et al., 1997). The spatial and temporal distributions of Trichodesmium sp. must be understood, to know the mechanics of the nitrogen inputs in the marine ecosystem. Cell counts, specifically trichome (filament) and colony counts, can be effective (Letelier and Karl, 1996; Post et al., 2002; Tyrrell et al., 2003). There is little study on Trichodesmium species identification in Central Visayas, Philippines. Although the size is usually microscopic, but when conditions are ideal for them both can undergo a phenomenon known as "bloom". Cyanobacteria are not always visible on the surface of water. Generally, they are largely in one particular area. Heavy blooms can overtake water bodies and even check out portions of stream or rivers. But it is difficult to predict when a bloom will occur. Trichomes and colonies vary in size and their counts may not represent true Trichodesmium biomass. Cell counts can be laborious, and identifying trichomes to species based on morphology can be confounding. Trichodesmium biomass was long been considered to be concentrated in the upper $50 \mathrm{~m}$ of the water column (Letelier and Karl, 1996; Carpenter et al., 2004). The collection of Trichodesmium species in this study via net tows is limited to surface and subsurface regions of at least 10m deep along the coastal margins, because long hauls may damage the fragile trichomes.

Classical identification of Trichodesmium was based on cell width and length, sheath characteristics, distribution of gas vesicles, and colony morphology. There are six well-described species of Trichodesmium: Trichodesmium contortum, Trichodesmium erythraeum, Trichodesmium hildebrandtii, Trichodesmium pelagicum (formerly Katagnymenespiralis and Katagnymenepelagica), Trichodesmiumtenue, and Trichodesmium thiebautii. Generally, two species T. erythraeum and T. thiebautii were common in the Philippine coastal marine environment. These species of Trichodesmium are genetically similar, but morphologically distinct. Classification by cell and colony morphologies can be confusing and misleading due to variable and overlapping characteristics (Anagnostidis and Komárek, 1988; Janson et al., 1995). Trichodesmium colonies come in a variety of morphologies including spherical puffs, fusiform tufts, and bowties. Some species can have more than one morphology, for example, T. thiebautii forms both puff and tuft colonies, and different species can have the same colony morphology: T. thiebautii, T. hildebrandtii, and T. erythraeum all form tufts. Single colonies may also contain a variety of filaments, indicating that they are not clonal and suggesting that colonies may coalesce from single trichomes of several species (Hynes et al., 2009). 
Many species originally identified as Trichodesmium were brought under the umbrella of the genus Oscillatoria and then later were separated back to Trichodesmium (Geitler, 1932; Rippka et al., 1979; Anagnostidis and Komárek, 1988). Species of the genus Katagnymene were found to be genetically similar to $T$. thiebautii with respect to the nitrogenase gene nifH, the $16 \mathrm{~S}-23 \mathrm{~S}$ internal transcribed spacer (ITS), and the heterocyst differentiation gene hetR, so Katagnymene spp. have been included in the genus Trichodesmium (Lundgren et al., 2001; Orcutt et al., 2002; Lundgren et al., 2005). A noninvasive study of Trichodesmium distributions using a video plankton recorder (VPR) reported high concentrations of Trichodesmium colonies as deep as $130 \mathrm{~m}$ (Davis and McGillicuddy, 2006). Trichodesmium thrives in iron-rich oligotrophic marine environment (Moore et al., 2009; Shiozaki et al., 2010, 2014).Phytoplankton are among the primary producers in shallow coastal areas and factors that affect them will most likely affect overall productivity of a given site. Hence, characterization of phytoplankton assemblages contributes to the determination of productive potential. In this study, the researcher was addressing the abundance and distribution of the genus Trichodesmium in DaanBantayan, Carmen, Balamban, and Dalaguete Cebu, Philippines.

\section{Materials ANd Methods}

\subsection{Sampling Site}

Collection of Trichodesmium was performed in the coastal waters of Dalaguete, Daan-bantayan, Carmen, and Balambanto represent the sampling sites (Figure 1). Themajor surrounding seas includes; Visayan Sea in the Northern part of Cebu and Bohol Sea in the southern part of Cebu, whereas; Camotes Sea in the eastern side and Tañon Strait in the western side of Cebu province. Actual fieldwork was conducted within last days of July to last days of September 2017 with a working timeframe of 10:00 in the morning until 2:00 in the afternoon.

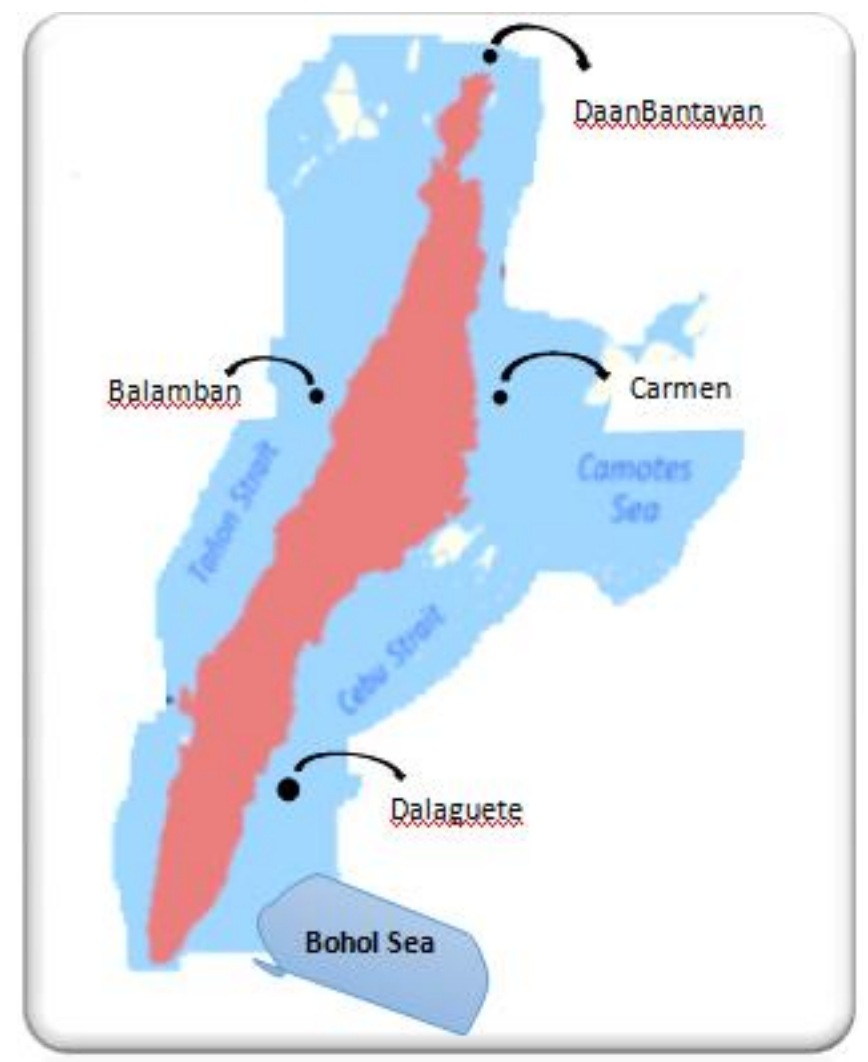

Figure1. Study sites for distribution and species identification of Trichodesmium

\subsection{Sample Collection and Preservation}

The phytoplankton was collected by towing a plankton net (mesh size: $20 \mu \mathrm{m}$, diameter: $0.5 \mathrm{~m}$, cod end volume: $100 \mathrm{ml}$ ) in the subsurface water at low running speed of motorized banca. After every 5minute tow, the filtered sample at the cod end was transferred directly to a pre-labeled $500 \mathrm{ml}$ container and fixed in Lugol's solution (Okolodkov, 2011). The next towed was started after a 5 minutes traveling interval to create a distance gap between tows. The plankton is left to settle then the 
top $250 \mathrm{ml}$ of the water will be carefully siphoned out with opening covered with plankton net to concentrate following the procedure of Yap-Dejeto, et al., 2013. The upper layer of water was then sucked out, leaving $200 \mathrm{~mL}$ of concentrated plankton sample, which was then transferred to $250 \mathrm{~mL}$ graduated cylinders. Sampling bottles were then rinsed. The plankton in the graduated cylinder to the bottom and transferred into a small bottle with cap was then allowed to settle for at least another $48 \mathrm{~h}$. The supernatant was sucked out once again, using a hooked capillary tube and pump, to leave about 20-50 $\mathrm{mL}$ of seawater and all collected plankton. The water samples were stored in a cooler under a temperature of at least $4^{\circ} \mathrm{C}$.For the first few samples, a series of $1 \mathrm{ml}$ aliquots were examined with the use of a Sedgwick-Rafter counting cell until the sampled water were empty.

\subsection{Isolation, Identification and Analysis}

After every field collection, a homogenized mixture of preserved sample was counted. Individual Trichodesmium cells were recorded per station, isolated for identification with photo documentation at $10-\mathrm{x}$ and 40-x magnification in a lighted compound microscope. Species level identification of Trichodesmium with the published guide of Tomas (1997),was used Okolodkov (2010), Gómez (2009)with the help of online resources. The identified species was taken a photo micrograph using phase contrast and differential inference contrast with a screen shot camera connected to a laptop computer as to the morphological profiling of the species. Mean total cell density and relative density of each of the genera identified were computed to determine percent contribution of the different genera to the phytoplankton community.

Total counts of species per surveyed area were presented in bar graphs. The work of Limates, et al., 2006 on the computation of relative cell density was used in the present study. In understanding the structure of the community, the relative abundance of the species was determined using the formula and was presented in the pie-chart:

\section{Relative density $=$ Total \# of cells per species $\quad$ x 100 \\ Total \# of cells for all species}

\section{RESULTS AND DISCUSSION}

\subsection{Density}

Two phytoplankton species have been identified under genus Trichodesmium using for at least $20 \mathrm{ml}$ standardized samples per sampled area (see Figure 2). As shown, the Trichodesmium thiebautii dominated comparably in three areas of Daanbantayan (3959 individuals), Balamban (3170), and Dalaguete (2948); whereas, very lowden sities observed in Carmen, Cebu. Dominated by Trichodesmium erythraeum from all sampled areas was in Carmen, Cebu having 629 individuals. The cell counts of Trichodesmium thiebautii was highest in Daanbantayanmarine waters which might correlates the good condition of the area and high nutrients. As reflected further in Figure 4 that the pattern of relative density among Balamban, Dalaguete and Daanbantayan seems comparable for $T$. erythraeum and for T. thiebautii. Following further onto this trend, Carmen composition and density of these species were very few (Figure 3). Trichodesmium can either live in a colonial habitat dominated by extensive physical interactions with both sister cells and other taxa and/or as free trichomes that can constitute a significant fraction of the Trichodesmium water column biomass (Orcutt et al., 2001).Field populations of Trichodesmium have previously been enumerated using cell counts (Letelier and Karl, 1996; Post et al., 2002; Tyrrell et al., 2003).

The surface Trichodesmium sp. relative density (Figure 4) were possibly correlated to depleted nitrogen in the area. Cyano bacteria of the genus Trichodesmium are often considered to be the principal $\mathrm{N}_{2}$-fixing diazotrophs in tropical and subtropical regions (Carpenter and Romans, 1991; Capone et al., 1997; Karl et al., 1997; Langlois et al., 2008; Rijkenberg et al., 2011). Thus, microscopic counts performed at USC Marine Station were showing evidences forthe abundance and pattern of distribution among Trichodesmium species mainly; Trichodesmium thiebautiiand $T$. erythraeum within the randomly selected stations (Figure 2 and 3). Their total counts at the surface were widely varied as reflected in Figures 3 and 4. Zooplankton being the first heterotroph consumer of phytoplankton T. erythraeum and T. thiebautii were observed lower in three stations as compared to Carmen station with 629 individuals. But it was also in Carmen site which the presence of $T$. thiebautii, has its lowest total counts for only 71 individuals among the four sites. 


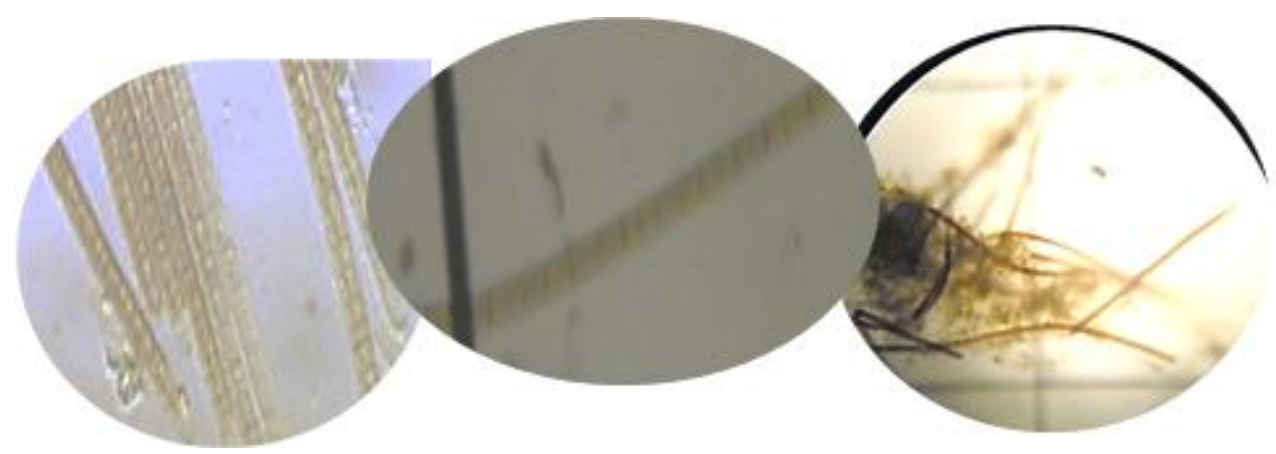

a) Trichodesmiumerythraeum

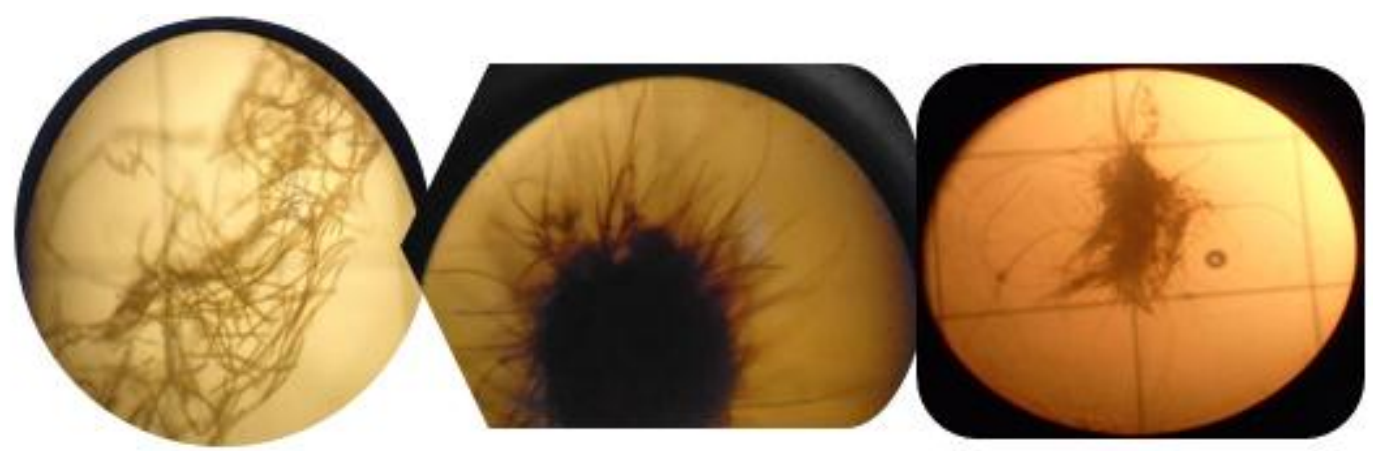

b) Trichodesmiumthiebautii

Figure2. Micrograph of Trichodesmium sp. at the surface of the study areas

\subsection{Trichodesmiumcounts and Composition}

The distribution of Trichodesmium is influenced by temperature (Heynes, 2009). Research on Trichodesmium sp. abundance and distribution is important for two reasons. First, they contribute a significant portion (at least 40\%) to global oceanic nitrogen fixation, and affects the biogeochemical carbon flux in tropical oceans, having connection with the climate condition. Second, massive coastal Trichodesmium blooms have toxic effects on invertebrates eating them and of other organisms that can potentially be harmful to humans (Karl et al., 2002; Devassy, 1979; Capone et al., 1997; Guo et al., 1994; Hawser et al., 1992; Lenes et al., 2001). The percen tage composition of genus Trichodesmium was presented in Figure 4.

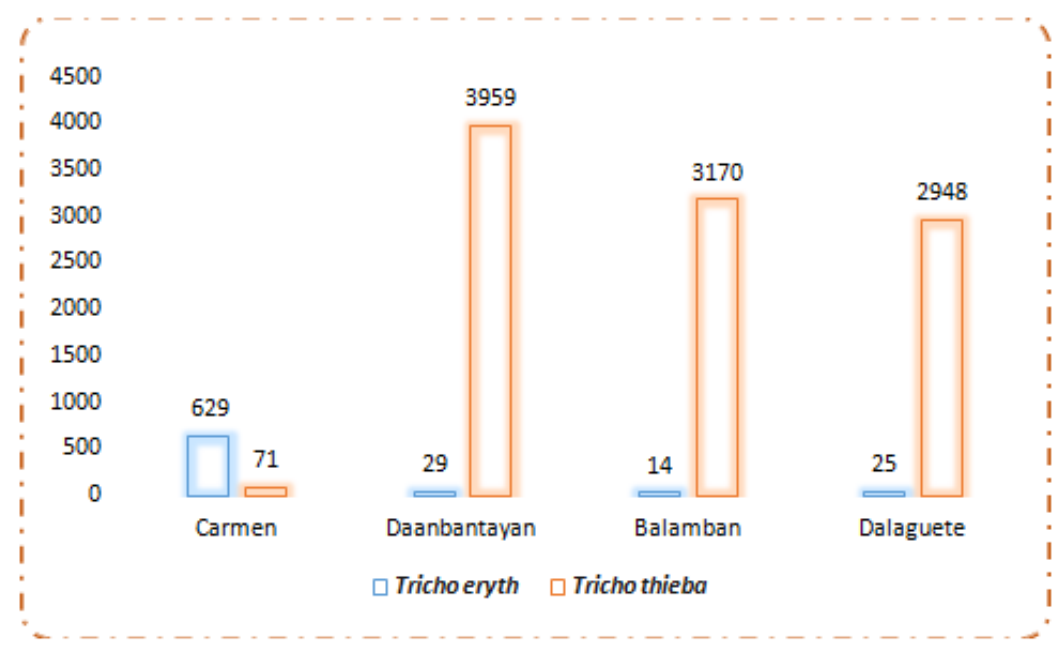

Figure3. Total count of major species of genus: Trichodesmium in selected sites in Cebu, Philippines (2017)

The collection of cyano bacteria was conducted from last days of July and ended during the last days of September 2017, where it falls to a wet season time. A study by Calompong et al., 2013 in Ticao Pass, Masbate, Philippines showed that blue-green algae, particularly Trichodesmium was abundant during this wet season. T. thiebautii and T. erythraeum are the main cyanobacteria forming large blooms if under favored conditions (Orcutt, 2002), and will cause harm to fishes (fishkills) and may 
kill humans. Abundance of these species in the Philippine Sea can be attributed to the high iron requirement of Trichodesmium sp. for their growth compared to other diazotrophs and nondiazotrophs (Kustka et al., 2003; Saito et al., 2011). And Trichodesmium species is a major nitrogen fixer in the Kuroshio (Chen et al., 2014; Shiozaki et al., 2015), which are often found in low-nutrient waters (Lin et al., 1998), during periods of low wind stress and warm temperatures (Lenes et al., 2005), not so exposed to wind influence.

In this study, areas being randomly selected as sampling sites were part of the existing major seas might affect with the distribution of the phytoplankton such as; Bohol sea in the South portion of Cebu and Visayan sea in the north, and Camotes Sea in South portion and Tañon Straitin the west (Figure 1). To consider the cyano bacteria in areas having business factory establishments as observed in Balamban and Carmen, Cebu and business beach resorts as were observed in coastal shorelines of Dalaguete. Whereas, freshwater discharge from the big river in Daanbantayan with anthropogenic activities and the presence of other coastal and marine ecosystems (i.e. mangrove ecosystem, sea grass ecosystem) might contributed to the highest number of Trichodesium thiebautii in this area.

Rough weather and strong currents with strong waves was experienced during the sampling days of July, 2017 in Balamban, Cebu, that might affect the abundance of Trichodesium erythraeum but not on T. thiebautii in contrast to the findings of Matsuno et al., 2006 that turbulence near the sea floor influences the surface water in the shallower bottom region, and Zhang et al. (2012) that the physical disturbance reduces diazotrophy since Trichodesmium favor calm seas. Usually the mangrove stands lined across the shorelines of the sampled coastal area, may enhanced nutrient inputs (Odum and Heald, 1975) that favors higher phytoplankton biomass in these areas with mangroves. Hence, the high cell counts of Trichodesmium assemblage in Daanbantayan, Dalaguete, and Balamban may be attributed to the high productivity of waters bordering it, and factors such as current and nutrient inputs which act on a more local scale as noted during the towing of the plankton net might be the reason for the relatively high overall concentrations of Trichodesmium thiebautii (10,148 individuals) accumulated among the four provinces.

Further, houses and other business establishments were observed and estimated within 250 meters from the sampling site in Balamban and Dalaguete, such that the high nutrient concentrations and loading resulted in changes in the species composition of phytoplankton (Colijn et al., 2002; Burford and Pearson 1998). Furthermore, the cyanophycean represented by genus Trichodesmium has shown uneven distribution across sampling periods and study sites. It was also possible that nutrients were one responsible for the observed spatial pattern within the towed sites as supported by various studies. Single colonies may also contain a variety of filaments, indicating that they are not clonal and suggesting that colonies may coalesce from single trichomes of several species (Hynes et al., 2009).Low presence of phosphorus and iron in marine environment will restrict the growth and $\mathrm{N}_{2}$ fixation capacity of Trichodesmium sp. (Moore et al., 2009) and their abundance (Shiozaki et al., 2015).

One of the emergent aspects in this present effort is to provide baseline data of the site, which might be determined by combinations of biological and physicochemical factors, diversity and abundance of primary producer and consumer assemblages, nutrient dynamics, water movement and overall habitat structure and complexity.

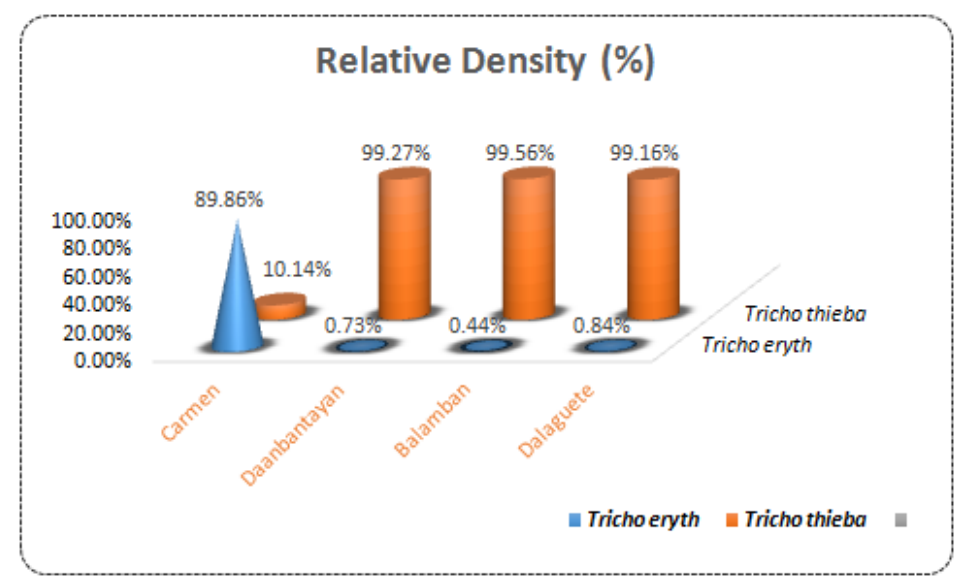

Figure4. Relative density of genus Trichodesmium from the four sampling site 


\section{CONCLUSION AND RECOMMENDATIONS}

Trichodesmium thiebautii was highest in Daanbantayan with 3959 individuals and and lowest in Carmen with 71 individuals. Similarly, Trichodesmium erythraeum was highest (629 ind.) in Carmen and lowest (14 ind.) in Balamban coastal area. Researcher hypothesized that the high abundance of Trichodesmium thiebautii were as crib able not only to the load of nutrient in the marine environment, favored temperature, but also onto the supply of Trichodesmium species and other phytoplankton and zooplankton from the selected areas; Balamban, Dalaguete, and Daanbantayan. In contrast, Trichodesmium erythraeum was observed lowest in these areas where T. thiebautii was abundant. Phytoplankton monitoring can be used as biological indicator and can give feedback on the quality of water as influenced by land use and nutrient inputs contributed by anthropogenic activities. Uneven abundance and distribution was observed in the four sites. Therefore, the abundance of Trichodesmium sp. Would likely be influenced by the nutrient availability, temperature and physical factors such as wet season (rainy season) and strong water currents, in the sampling site in favor of the specific species of Trichodesmium.

As such, monitoring should be conducted regularly and institutionalized to determine the impact of nutrient loading to the coastal water, and can provide feedback on the ecological status of the coastal ecosystem particularly the quality of the coastal waters within the Cebu provinces. Implementation of strong multi-sectoral monitoring (from private NGOs to concerned bureau such as DOST and academe such as CTU) is deemed necessary. Lessons learned from genus Trichodesmium can be applied to other species of phytoplankton which are not as well studied. It is further suggested to study their abundance and distribution during dry season and summer months.

\section{ACKNOWLEDGEMENTS}

The authors wish to thank Arvin C. Balala for the assistance in the identification of Trichodesmium and Marine Bio Laboratory people for their support and assistance in both the field and laboratory.

\section{REFERENCES}

Anagnostidis, K. and J. Komirek. 1988. Modern approach to the classification system of Cyanophytes Oscilatoriales. Arch. Hydrobiol. Suppl., 80:327-472.

Burford, M. A. and D.C. Pearson. 1998. Effect of different nitrogen sources on phytoplankton composition in aquaculture ponds. Aquatic Microbial Ecology. Vol. 15: 227-284.

Calumpong, H.P., Sienes, P.M., Santos, T.R., Padin, J.M., and Edna R. Sabater. 2013. Plankton abundance in Ticao, Masbate, Philippines. Ecol. Env. \& Cons. 19: 47-51.

Capone, D. G., J. Zehr, H. Paerl, B. Bergman, and E. J. Carpenter. 1997. Trichodesmium: A globally significant marine cyanobacterium. Science. 276:1221-1229.

Carpenter, E. J., A. Subramaniam, and D. G. Capone. 2004. Biomass and primary productivity of the cyanobacterium Trichodesmium sp. in the tropical N Atlantic Ocean. Deep Sea Res. I,51:173-203.

Carpenter, E. J. and K. Romans. 1991. Major role of the cyano bacterium Trichodesmium in nutrient cycling in the North Atlantic Ocean. Science, 254, 1356-1358.

Chen, Y. L. L., Chen, H. Y., Lin, Y. H., Yong, T. C., Taniuchi, Y., and S.H. Tuo. 2014. The relative contributions of unicellular and filamentousdiazotrophs to N2 fixation in the South China Sea and the upstream Kuroshio, Deep-Sea Res. Pt. I, 85: 56-71.

Colijn, F., Hesse, K.J., Ladwig, N., Tillmann, U., Vadstein, O., Olsen, Y. 2002. Effects of the Large Scale Uncontrolled Fertilization Process Along the Continental Coastal North Sea. Hydrobiologia.

Davis, C. S. and D. J. McGillicuddyJr. 2006, Transatlantic abundance of the N2-fixing colonial cyano bacterium Trichodesmium. Science. 312:1517-1520.

Devassy, V. P., P. M. Bhattathiri, and S. Z. Qasim. 1979. Succession of organisms following Trichodesmium phenomenon. Indian J. Mar. Sci. 8: 88-93.

Geitler, L. 1932. Cyanophyceae. In L. Rabenhorst (ed.), Kryptogammenfloravon Deutschland, Osterreich, under de Sweit. Akademische Verlagsgesellschaft, Leipzig vol. 14: pp. 673-1056.

Guo, C., and P. A. Tester. 1994. Toxic effect of the bloom-forming Trichodesmium sp. (cyanophyta) to the copepod Acartiatonsa. Nat. Toxins.2:222-227.

Hawser, S. P., J. M. O'Neil, M. R. Roman, and G. A. Codd. 1992. Toxicity of blooms of thecyano bacterium Trichodesmiumt o zooplankton. J. Appl. Phycol. 4: 79-86. 
Hynes, A. M., P. D. Chappell, S. T. Dyhrman, S. C. Doney, and E. A. Webb. 2009. Cross-basin comparison of phosphorus stress and nitrogen fixation in Trichodesmium. Limnology and Oceanography. 54 (4): 14381448.

Janson, S., P. J. A. Siddiqui, A. E. Walsby, K. M. Romans, E. J. Carpenter, and B. Bergman. 1995. Cytomorphological characterization of the planktonic diazotrophic cyano bacteria Trichodesmiumsp. from the Indian Ocean and Caribbean and Sargasso Seas. J. Phycol. 31:463-477.

Karl, D.M., Michaels, A., Bergman, B., Capone, D., Carpenter, E., Letelier, R.,

Lipshultz, F., Paerl, H., Sigman, D., and L. Stal. 2002. Dinitrogen fixation in the world's oceans. Biogeochem. 57-58:47-98.

Karl, D. M., Letelier, R., Tupas, L. et al. 1997. The role of nitrogen fixation in biogeochemical cycling in the subtropical North Pacific. Nature, 388: 533-538.

Kutska, A. B., Sañudo-Wilhemy, S. A., Carpenter, E. J. et al. 2003. Iron requirements for dinitrogen- and ammonium-supported growth in cultures of Trichodesmium (IMS 101): comparison with nitrogen fixation rates and iron: carbon ratios of field populations. Limnol. Oceanogr.48: 1869-1884.

Langlois, R. J., Hummer, D. and J. LaRoche. 2008. Abundances and distributions of the dominant nifHphylotypes in the northern Atlantic Ocean. Appl. Environ. Microbiol.74: 1922-1931.

Lee, R. E. 2008. Phycology, 4th edition. Cambridge University Press, United Kingdom. pp. 33-80.

Lenes, J.M., Walsh, J.J., Otis, D. and K.L. Carder.2005. Iron Fertilization of Trichodesmium off the West Coast of Barbados: A One-Dimensional Numerical Model. Deep Sea Research Part I: Oceanographic Research Papers. 52(6):1021-1041.

Lenes, J. M., Darrow, B. P., Cattrall, C. et al. 2001. Iron fertilization and the Trichodesmium response on the West Florida shelf. Limnol. Oceanogr.46: 1261-1277.

Letelier, R. M. and D. M. Karl, 1996: Role of Trichodesmium sp. in the productivity of the subtropical North Pacific Ocean. Marine Ecology Progress Series. 133: 263-273.

Limates, V.G., Cuevas, V.C., Tajolosa, A.T., and E. Benigno. 2006. Phytoplankton Abundance and Distribution in selected sites of Boracay Island, Malay, Aklan, Central Philippines. J. Environ. Sci and Manage. 2: 1-14.

Lin, S., Henze, S., Lundgren, P. Bergman, B. and E.J. Carpenter. 1998. Whole-cell Immunolocalization of Nitrogenase in Marine Diazotrophic Cyanobacteria, Trichodesmium sp. Applied and Environmental Microbiology, 64(8): 3052-3058.

Lundgren, P., S. Janson, S. Jonasson, A. Singer, and B. Bergman. 2005, Unveiling of novel radiations within Trichodesmiumcluster by hetRgene sequence analysis. Appl.Environ. Microbiol. 71:190-196.

Lundgren, P., E. Siderbick, A. Singer, E. J. Carpenter, and B. Bergman. 2001, Katagnymene: characterization of a novel marine diazotroph. J. Phycol. 37:1052-1062.

Matsuno, T., Lee, J. S., Shimizu, M., Kim, S. H., and I.C. Pang, I. C. 2006. Measurements of the turbulent energy dissipation rate " and an evaluation of the dispersion process of the Changjiang diluted water in the East China Sea, J. Geophys. Res. 111, C11S09. (doi:10.1029/2005JC003196).

Moore, C. M., Mills, M. M., Achterberg, E. P., Geider, R. J., LaRoche, J., Lucas, M. I., McDonagh, E. L., and X. Pan, 2009. Poulton, A. J., Rijkenberg, M. J. A., Suggett, D. J., Ussher, S. J., and Woodward, E. M. S.: Large-scale distribution of Atlantic nitrogen fixation controlled by iron availability, Nat. Geosci. 2: $867-871$.

Odum, W.E. and E. J. Heald. 1975. The detritus-based food web of an estuarine mangrove community. In: Cronin, L.E. (ed.), Estuarine Research. vol. 1, Academic Press. New York. 265-286 p.

Okolodkov, Y.B. 2011. Division Dinoflagellata (Bütschli) Fensome, Taylor, Norris, Sarjeant, Wharton et Williams. 1993. p. 7-119 in S.A. Karpov (ed.). Protista, part 3. Guide-book on Zoology. St. PetersburgMoscow: KMK Sci. Press.

Orcutt, K. M., U. Rasmussen, E. A. Webb, J. B. Waterbury, K. Gundersen, and B. Bergman. 2002. Characterization of Trichodesmiumspp. by genetic techniques. Appl. Environ. Microbiol. 68: 2236-2245.

Orcutt, K.M., Lipschultz, F., Gundersen, K., Arimoto, R., Michaels, A.F., Knap, A.H., and J.R. Gallon. 2001. A seasonal study of the significance of N2 fixation by Trichodesmium sp. At the Bermuda Atlantic Time-series Study (BATS) site.Deep- Sea Res. II48: 1583-1608.

Post, A. F., Z. Dedej, R. Gottlieb, H. Li, D. N. Thomas, M. El-Absawi, A. El-Naggar, M. El-Gharabawi, and U. Sommer. 2002. Spatial and temporal distribution of Trichodesmium sp. in the stratified Gulf of Aqaba, Red Sea. Mar Ecol. Prog. Ser, 239:241-250.

Rijkenberg, M. J., Langlois, R. J., Mills, M. M. et al. 2011. Environmental forcing of nitrogen fixation in the eastern tropical and sub-tropical North Atlantic Ocean. PLoSONE. 6: e28989.

International Journal of Research Studies in Biosciences (IJRSB)

Page $\mid 12$ 
Rippka, R., J. Deruelles, J. B. Waterbury, M. Herdman, and R. Y. Stanier. 1979. Generic assignments, strain histories, and properties of pure cultures of cyanobacteria. J. Gen.Microbiol.111:1-61.

Saito, M. A., Bertrand, E. M., Dutkiewicz, S., Bulygin, V. V., Moran, D. M., Monteiro, F. M., Follows, M. J., Valois, F.W., and J.B. Waterbury. 2011. Iron conservation by reduction of metalloenzymeinventories in the marine diazotroph Crocosphaerawatsonii, P. Natl. Acad. Sci. USA. 108: 2184-2189.

Shiozaki, T., S. Takeda, S., S. Itoh, S., T. Kodama, T., X. Liu, X., F. Hashihama, F., and K. Furuya.2015. Why is Trichodesmiumabundant in the Kuroshio?Biogeosciences. 12: 6931-6943.

Shiozaki, T., Ijichi, M., Kodama, T., Takeda, S., and K. Furuya. 2014b. Heterotrophic bacteria as major nitrogen fixers in the euphotic zone of the Indian Ocean, Global Biogeochem. C. 28: 1096-1110.

Shiozaki, T., Chen, Y. L. L., Lin, Y. H., Taniuchi, Y., Sheu, D. S., Furuya, K., and H. Y.Chen. 2014a. Seasonal variations of unicellular diazotroph groups A and B, and Trichodesmiumin the northern South China Sea and neighboring upstream Kuroshio Current, Cont. Shelf Res. 80: 20-31.

Shiozaki, T., Furuya, K., Kodama, T., Kitajima, S., Takeda, S., Takemura, T., and Kanda, J. 2010. New estimation of $\mathrm{N} 2$ fixation in the western and central Pacific Ocean and its marginal seas, Global Biogeochem. C. 24: (doi:10.1029/2009GB003620).

Tyrrell, T., E. Marafin, A. J. Poulton, A. R. Bowie, D. S. Harbour, and E. M. S. Woodward. 2003. Largescale latitudinal distribution of Trichodesmiumsp. in the Atlantic Ocean. J. Plankton Res. 25:405-416.

Tomas, C. 1997. Identifying Marine Phytoplankton. Academic Press, San Diego. 856 pp.

Yap-Dejeto, L.G., TakuoOmura, T., Genneline F. Cinco, G.F., Cobacha, M.M., and

YasuwoFukuyo. 2013. Species Account of Marine Diatoms of the Genus Pseudo-nitzschia in San Pedro Bay, Philippines. Phil. Journ. Sci. 142(1): 27-37.

Zhang, R., Chen, M., Cao, J., Ma, Q., Yang, J., and Y. Qiu. 2012. Nitrogen fixation in the East China Sea and southern Yellow Sea during summer 2006, Mar. Ecol.-Prog. Ser. 447: 77-86.

Citation: A. Melendres \& Filipina B. Sotto, "Density Account of Cyanobacteria (Genus: Trichodesmium) in Selected Cebu Provinces, Philippines", International Journal of Research Studies in Biosciences (IJRSB), vol. 5, no. 11, pp. 6-13, 2017. http://dx.doi.org/10.20431/2349-0365.0511002

Copyright: (C) 2017 Authors. This is an open-access article distributed under the terms of the Creative Commons Attribution License, which permits unrestricted use, distribution, and reproduction in any medium, provided the original author and source are credited. 